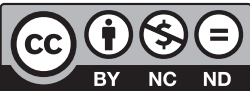

Estudos Teológicos foi licenciado com uma Licença Creative Commons Atribuição - NãoComercial - SemDerivados 3.0 Não Adaptada

http://dx.doi.org/10.22351/et.v58i2.3106

\title{
LIÇÕES DO ABISMO: \\ Reflexões sobre teologia, mística e poesia em Rubem Alves ${ }^{1}$ \\ Lessons from the abyss: \\ Reflections on theology, mysticism and poetry in Rubem Alves
}

\section{Breno Martins Campos ${ }^{2}$ \\ Ceci Maria Costa Baptista Mariani ${ }^{3}$}

Resumo: A resistência à mística no protestantismo histórico brasileiro pode ser observada na realidade da maior parte de suas igrejas e denominações. Na contramão desse modelo hegemônico, este artigo traz à memória a figura de Rubem Alves como um autor que enriqueceu a tradição teológica latino-americana da libertação com uma obra que pode ser considerada teopoética. Em sua vertente mística, a teologia do protestante Rubem Alves encontrou na poesia a forma privilegiada de expressão, a linguagem que propicia a expressão da experiência espiritual do mistério que se dá no corpo. A mística que se encontra na teopoética de Rubem Alves caracteriza-se por uma maneira interessante de lidar com o desejo: sem negar o corpo, entende que a realização humana supõe uma ascese do desejo, isto é, um processo em que a vivência de si como ser desejante encontra-se sempre tensionada pela percepção do Vazio originário, o Mistério inefável e inominável que habita a profundidade do humano, o fundo da alma. Para alcançar a dimensão que a discussão merece e para atingir os objetivos epistemológicos propostos, este artigo, situado no âmbito da pesquisa sobre a linguagem da experiência religiosa, especificamente relacionada à compreensão da mística como crítica, utiliza-se de abordagem teórica e qualitativa, e se fundamenta no levantamento e estudo bibliográficos e seus suportes.

Palavras-chave: Rubem Alves. Teopoética. Mística. Reforma. Linguagem.

Abstract: The bias against the mysticism of Brazilian historical Protestantism can be observed commonly at most of its churches and denominations. Contrary to this hegemonic model, this article brings up Rubem Alves as an author who enriched the tradition of liberation theology in Latin America, with a body of work that can be regarded as theopoetic. In its mystical aspect, protestant Rubem Alves' theology

1 O artigo foi recebido em 29 de agosto de 2017 e aprovado em 07 de maio de 2018 com base nas avaliações dos pareceristas ad hoc.

2 Doutor em Ciências Sociais. Membro do corpo docente permanente do PPG em Ciências da Religião da PUC-Campinas. Campinas-SP, Brasil. Contato: brenomartinscampos@gmail.com

3 Doutora em Ciências da Religião. Membro do corpo docente permanente do PPG em Ciências da Religião da PUC-Campinas. São Paulo-SP, Brasil. Contato: cecibmariani@gmail.com 
meets the privileged form of expression in poetry, that is, it finds a language that allows to express the spiritual experience of the mystery that takes place in the body. The mysticism that finds itself in Rubem Alves' theopoetics is characterized by an unconventional way to deal with the desire: without denying the body, he understands that human achievement supposes an asceticism of the desire, in other words, it is a process in which the experience of self as a desiring being is always strained by the perception of the original Void, the ineffable and unnamable Mystery that inhabits the depth of humanness, the depth of the soul. This article falls under the scope of the research on the language of religious experience, specifically related to the understanding of mysticism as a form of criticism. In order to reach the depth that this discussion deserves and to achieve the proposed epistemological objectives, this piece makes use of theoretical and qualitative approach, and it is based on research and study of selected bibliography and its supporting material.

Keywords: Rubem Alves. Theopoetics. Mysticism. Protestantism. Language.

\section{Considerações iniciais}

Antes de tratar propriamente de Rubem Alves, e com o objetivo de delimitar o objeto de pesquisa, este artigo parte do pressuposto tácito de que há uma dificuldade na associação da mística com o protestantismo histórico no Brasil, dada a ênfase de suas igrejas e denominações - a maioria de origem missionária - na centralidade da Palavra (Escrituras Sagradas), na iniciativa divina para a salvação e na exigência de um rigoroso comportamento moral de todos os fiéis. A impropriedade teológica de se encontrar uma mística em boa parte da tradição herdeira da Reforma - no mundo todo, pois o caso brasileiro não é uma exceção à regra - é reforçada se a compreensão de mística for assumida como o ápice na união com o divino, ou seja, como uma identificação indiferenciada entre o finito e o infinito, uma metafísica da união.

Segundo Bernard McGinn, a tradição teológica protestante - especialmente a alemã - construiu e sustenta uma avaliação negativa da mística, pois a identifica com a prática da metafísica neoplatônica. Por exemplo, Adolf von Harnack, pai da teologia liberal, entende que a noção de nascimento do Logos na alma do crente - o que corresponde à deificação para o cristianismo oriental - implicava panteísmo e, consequentemente, uma visão mágica dos sacramentos. A posição harnackiana de crítica à mística pode ser considerada típica do protestantismo na Europa continental do século XX. Mesmo aqueles que reagiram contra a teologia liberal - Karl Barth e Emil Brunner, dentre outros - têm posição semelhante à de Harnack em relação à mística. ${ }^{4}$

Outros estudiosos da mística, no entanto, recorrendo à história da utilização do termo, propõem uma compreensão mais ampla. Tendo nascido no seio da tradição cristã, a palavra mística, que é a transcrição do adjetivo grego mystikós, oferece, no contexto de encontro do cristianismo com a cultura grega, recursos simbólicos para fazer referência ao mistério da encarnação do Verbo de Deus. Para os Padres Gregos,

4 MCGINN, Bernard. As fundações da mistica: das origens ao século V. São Paulo: Paulus, 2012. Tomo I. 
místico é o conhecimento das coisas divinas, às quais se consegue ascender por meio de Cristo. ${ }^{5} \mathrm{Na}$ sua origem, o termo tem caráter exegético, isto é, diz respeito à leitura e interpretação da Bíblia, ao esforço de penetrar a profundeza da Palavra de Deus como locus da revelação do mistério de Deus.

De importância definitiva para a compreensão do termo mística deve ser apresentado o pequeno tratado intitulado Teologia Mística, do Pseudo-Dionísio Areopagita, escritor monástico que viveu por volta de 500 d.C. Foi ele que cunhou a expressão "Teologia Mística", por meio da qual se oferece expressão sistemática a uma visão dialética da relação de Deus com o mundo e que exerce grande influência na teologia. ${ }^{6}$ Mística passa a ser, então, o adjetivo a qualificar um procedimento teológico que tem no seu centro a dialética da negação. Conforme a compreensão do Pseudo-Dionísio Areopagita, mística é a teologia que busca penetrar, mediante a remoção, os mistérios simples, absolutos e imutáveis revelados na "Treva Superluminosa" do silêncio que ensina ocultamente. A Teologia Mística implica, portanto, uma dialética ascendente que envolve afirmações e negações.

Com efeito, afirmamos, quando partimos dos princípios mais originários e descemos através dos membros intermédios às últimas coisas; no caso das negações, todavia, removemos tudo, quando subimos das últimas coisas às mais originárias, para conhecer a ignorância escondida em todos os seres por todas as coisas cognoscíveis, e para ver a treva supernatural escondida por todas as luzes presentes nos seres. ${ }^{7}$

O Areopagita mostra que a relação com o Deus absolutamente transcendente implica êxtase operado pelo procedimento da negação (remoção), com a finalidade última da união transformadora (divinização) pelo amor que é Deus, absolutamente transcendente e totalmente presente em toda a criação. Mística é uma qualidade da teologia, um tipo de sabedoria de Deus em que penetram os iniciados que se dispõem ao despojamento do próprio saber; e que, abandonando-se de forma irrestrita, absoluta e pura, deixam-se conduzir para o alto para viver naquele que a tudo transcende, unindo-se ao princípio superdesconhecido, segundo o melhor de suas faculdades, mas conhecido para além da inteligência. ${ }^{8}$

A palavra mística veio a ser utilizada como substantivo e para designar pessoas somente no século XVII. A partir do estudo de místicos franceses do século XVII, Michel de Certeau demonstrou que houve uma transformação importante no entendimento do fenômeno místico, que passa a ser compreendido como conhecimento experimental dissociado da teologia ou de instituições eclesiásticas - trata-se de uma passividade gratificada pela qual o eu se perde em Deus. ${ }^{9}$ Essa nova compreensão

5 BOUYER, Louis. Mystique. Essai sur l'histoire d'un mot. Supplément à la Vie Spirituelle, n. 9, p. 3-23, 15 maio 1949.

6 MCGINN, 2012.

7 PSEUDO-DIONÍSIO AREOPAGITA. Teologia Mistica. Rio de Janeiro: Fissus, 2005. p. 21-22.

PSEUDO-DIONÍSIO AREOPAGITA, 2005.

9 Michel de Certeau apud MCGINN, 2012, p. 445-446. 
assume a iluminação particular e as experiências psicossomáticas incomuns como critérios de identificação do fenômeno; além disso, possibilita caracterizar as pessoas como místicas, bem como distinguir uma tradição mística.

O deslocamento experimentado pelo termo provoca um importante debate no interior da teologia católica entre os que afirmam a mística como uma graça especial e os que defendem a contemplação mística como a meta normal da vida cristã, isto é, a mística como uma forma intensiva de experiência de Deus na fé. ${ }^{10}$ Também a contribuição de Karl Rahner é muito significativa no debate: com o tema da orientação do sujeito finito para o infinito, Rahner tem sido um importante porta-voz da tradição apofática, já que, para ele, Deus permanece Mistério. Assim, a mística se articula na obra de Rahner não como uma experiência particular, mas com a teologia fundamental do autor, isto é, com sua compreensão de revelação como autocomunicação de Deus ao sujeito que se abre ao Mistério Último (experiência transcendental). ${ }^{11}$ Ainda que marcadamente cristocêntrica, a perspectiva de Rahner propicia refletir sobre a mística também fora do cristianismo.

Em face de um amplo estudo histórico como referência, McGinn propõe definir mística como consciência da presença divina. Afirma ainda que, para melhor compreender o termo, é preciso considerar três elementos: mística como parte ou elemento da religião, mística como um processo ou modo de vida, e mística como tentativa de expressar uma consciência direta da presença de Deus. Além disso, entende que, em princípio, o elemento místico é aquela parte (da crença ou das práticas) que diz respeito à preparação para a consciência da presença de Deus e à reação ante essa presença captada como presença direta, isto é, sem mediação. Os modos desse encontro têm sido compreendidos de múltiplas formas. É certo, porém - e sobre isso existe muita concordância entre os testemunhos e estudos -, que a experiência mística desafia a conceituação e a verbalização, e só pode ser expressa recorrendo-se a estratégias verbais que não objetivem a informação, mas a condução do ouvinte ou do leitor à consciência da presença divina. ${ }^{12}$

Importa salientar, entretanto, que o modo dessa presença vivenciada e percebida no processo denominado místico revela uma faceta decisiva da relação com o divino, a inefabilidade. Em função da incomensurabilidade entre o Sujeito Infinito e o sujeito finito, os místicos não se expressam usando uma linguagem positiva, mas buscam formas de expressão que indiquem a paradoxal e simultânea experiência de presença e ausência do divino. Ao longo da tradição mística, algumas categorias foram utilizadas como forma de se referir ao fenômeno místico: contemplação, visão de Deus, deificação, nascimento do Verbo na alma, êxtase, obediência à vontade divina presente. ${ }^{13}$

Sob a referência dessa compreensão ampla de mística é que se propõem aqui algumas reflexões acerca da relação entre teologia, mística e poesia em Rubem Alves, focando especialmente o livro A planície e o abismo, obra em que é possível distin-

\footnotetext{
10 SCHILLEBEECKX, Edward. História humana, revelação de Deus. São Paulo: Paulus, 1994.

11 MCGINN, 2012.

12 MCGINN, 2012.

13 MCGINN, 2012.
} 
guir com clareza elementos místicos na narrativa poética do autor, uma teopoética. ${ }^{14}$ Para Rubem Alves, a consciência da Presença se revela na percepção de uma grande Ausência - a presença de um desejo profundo que não tem solução faz emergir a intuição do Transcendente. A teologia poética de Rubem Alves traz em sua base uma compreensão de religião que tem como referência a experiência mística.

Em Rubem Alves, o termo "religião" pode se referir tanto a uma experiência mística quanto à rede de símbolos que essa experiência mística evoca (embora a ênfase se concentre nesta última). A religião (enquanto experiência com o sagrado e mesmo enquanto sistema de crenças) é um universo simbólico que não tem a pretensão de explicar a realidade, mas expressar aquilo que se encontra ausente. ${ }^{15}$

Na primeira seção deste artigo, Rubem Alves é apresentado como habitante do mundo protestante tradicional, com destaque para suas críticas ao modus operandi de igrejas e denominações protestantes que acabaram por cair na tentação de privilegiar a manutenção do status quo. Na segunda, ele aparece como um reformado sempre se reformando: intelectual ousado e original, teólogo que soube articular a mística, a poesia e a teologia. Na terceira, pela análise interpretativa de A planície e o abismo, são apontados os elementos místicos que caracterizam a narrativa desse livro como um exemplo da teopoética do autor.

\section{Rubem Alves, um habitante do mundo protestante}

A palavra mundo pode adquirir significados multifacetados em frases ou contextos diferentes, porém, aqui, o sentido pretendido para expressão "mundo protestante" vem da explicação de Rubem Alves ao analisar o que ele chama de ideologia protestante: o mundo protestante é comparado ao jogo de xadrez - com suas peças, regras, objetivos, linguagem, especificidades etc. - ou à receita de um bolo - com seus ingredientes, forma de bater a massa, tempo de cozimento etc.; "[...] ideologias são mundos, círculos, a um tempo lares e túmulos, onde vivemos e morremos. Entrar numa ideologia é entrar num destes mundos, único, com regras próprias e cores específicas"16.

Sobre a linguagem como construtora de mundos, Rubem Alves nunca deixou de reconhecer as palavras de um mundo que lhe foi apresentado quando criança, o mundo protestante. Palavras que não se deixam esquecer (não podem ser esquecidas) e por isso mesmo constituíam as memórias do autor; na forma de prelúdio de uma confissão, escreve Rubem Alves: "sou protestante. Sou porque fui""17 - de modo diferente em cada momento distinto, mas protestante sempre.

\footnotetext{
14 ALVES, Rubem. A planície e o abismo. São Paulo: Paulinas, 1991.

15 REBLIN, Iuri Andréas. Outros cheiros, outros sabores...: o pensamento teológico de Rubem Alves. São Leopoldo: Oikos, 2009. p. 126.

16 ALVES, Rubem. Dogmatismo e tolerância. São Paulo: Paulinas, 1982a. p. 22.

17 ALVES, 1982a, p. 9.
} 
O meu mundo, único e diferente de todos os outros, é o mundo que conheço e chamo pelo nome. Veio a existir por meio da linguagem. Primeiro a linguagem da minha mãe, pai, irmãos, que me disseram como as coisas se chamam, e por que elas são do jeito que são. Foram elas que me introduziram ao mundo dos deuses e demônios, do pecado e da culpa, do perdão e da alegria. ${ }^{18}$

Rubem Alves corrobora ainda a noção de que a realidade não é contemplada face a face: "Desde que nascemos, as coisas não vêm a nós em sua nudez, mas sempre vestidas pelos nomes que uma comunidade lhes deu, comunidade que já definiu como é o mundo e que, portanto, sabe o que ele é. Este conhecimento do mundo está cristalizado na linguagem" "19. Linguagem que é sempre uma interpretação, um mapa seletivo da realidade social. Linguagem, propriedade dos falantes, que se encarna num discurso - que é próprio de uma comunidade específica de falantes.

O Protestantismo privilegia a palavra em oposição à contemplação. Isto não é acidental. Tem raízes teológicas. Em contraposição aos católicos, que enfatizam a dimensão contemplativa e visual da experiência religiosa, os protestantes viram no segundo mandamento um interdito que lhes impôs um rigoroso ascetismo artístico. "Não farás para ti imagem de escultura": o divino não pode ser representado. Representar o divino é idolatria. Já que o divino não pode ser representado pela forma, pela cor e pelo movimento, restou ao Protestantismo indicá-lo por meio da linguagem. Esta é a razão por que o meio por excelência pelo qual os protestantes vivem a religião é a linguagem: eles pregam, eles ouvem, eles cantam. ${ }^{20}$

É pelo discurso que o protestantismo propõe uma experiência religiosa aos fiéis. As verdadeiras doutrinas e interpretações pressupõem a existência de um grupo que se organiza em torno da verdade. Pode-se dizer que as doutrinas definem o grupo religioso e dão sentido a ele, protegendo-o das novidades que colocam em risco o bem-estar da coletividade. Contra as novidades, a tarefa da teologia protestante tem sido a de interpretar, reconstruir e sistematizar a tradição. Rubem Alves trabalhou o tema de um modo bastante original e provocativo: a interpretação literal ou não dos textos bíblicos, apesar de todos eles estarem dentro do conceito doutrinário da inerrância ou infalibilidade da palavra de Deus, depende do modo em que se encontra o verbo, indicativo ou imperativo. ${ }^{21}$

Por um lado, a interpretação de algumas passagens bíblicas que se apresentam no modo verbal imperativo não pode ser literal, ou seja, ninguém precisa arrancar o

${ }_{18}$ ALVES, 1982a, p. 22.

19 ALVES, Rubem. Protestantismo e repressão. 2. reimp. São Paulo: Ática, 1982b. p. 54. Para uma leitura do diálogo crítico de Rubem Alves com a sociologia do conhecimento (de Peter Berger e Thomas Luckmann, dentre outros autores e escolas do pensamento sociológico) quanto à construção e da manutenção do mundo como realidade social, cf. CAMPOS, Breno Martins; MARIANI, Ceci Maria Costa Baptista. Peter Berger e Rubem Alves: religião como construção social entre a manutenção do mundo e a libertação. Protestantismo em Revista, v. 36, p. 3-20, jan./abr. 2015.

${ }^{20}$ ALVES, 1982b, p. 131-132.

${ }^{21}$ ALVES, 1982b. 
olho que faz tropeçar - conforme as palavras de Jesus no sermão da montanha em suas orientações quanto ao tema do divórcio - nem vender tudo o que tem e entregar aos pobres, seguindo o mandato de Jesus ao jovem rico. Por outro lado, existem textos no modo indicativo que exigem uma interpretação literal, por exemplo, o da criação em seis dias ou o da história de Jonas que foi engolido por um peixe. A tese de Rubem Alves é que os textos bíblicos no modo indicativo devem ser interpretados literalmente porque narram os fatos como eles se deram. Representadas por suas autoridades religiosas, as igrejas e denominações protestantes têm interpretado a Bíblia segundo seus interesses, quais sejam, os de garantir a sobrevivência de seu discurso. Daí que Rubem Alves possa introduzir mais uma variante ao tema e à discussão: a tarefa do teólogo protestante no Brasil é repetir e justificar o que está dado. ${ }^{22}$

Para excluir a concorrência dos que são portadores de pensamento alternativo, os mantenedores do status quo fazem uso de muitos artifícios e instrumentos, sendo que o principal e mais forte dos instrumentos de legitimação é a doutrina. Isso não dispensa o concurso de métodos de natureza inquisitorial: "Nenhuma linguagem pode assimilar conceitos estranhos a si mesma, sem com isso condenar-se à destruição. Conceitos estranhos são germes invasores, daí a necessidade de inquisições, os antibióticos político-sociais. Os hereges têm de ser queimados"23. Quaisquer variações precisam ser eliminadas, pois a antropologia protestante define o ser humano não simplesmente como um ser-no-mundo, mas como um ser-perante-a-eternidade.

Que palavras os protestantes usam? Deus, céu, inferno, salvação, Jesus Cristo, conversão, santificação, tentação, o crente, o mundo, pecado, confissão, oração - aqui estão algumas delas. E quando são usadas, um universo se constitui.

É este universo, assim constituído, que forma o mundo protestante. Ele é sagrado. Tem de ser preservado. Os neófitos passam pela cuidadosa preparação que os habilita ao jogo linguístico. ${ }^{24}$

Assim é que o além interfere diretamente na vida humana com promessas de punição ou de recompensa, favorecendo a manutenção do discurso que dá sentido ao status quo religioso, e também eliminando o perigo das heresias. "Esta é a razão por que é mais seguro habitar o mundo da linguagem que frequentar a própria vida." ${ }^{25} \mathrm{Em}$ contrapartida, o tom pessimista ou determinista da discussão alcança outra perspectiva no próprio corpus bibliográfico de Rubem Alves. Iuri Andréas Reblin, ao discutir, por exemplo, a teologia de Rubem Alves como poema do corpo, aponta que a mesma linguagem que aprisiona pode libertar, pois ela se revela como "reverberação do corpo": necessidade de vida, desejo de significado, assim, o mundo pode ser reinventado (de novo e sempre), não há limites para a imaginação. ${ }^{26}$

\footnotetext{
${ }^{22}$ ALVES, $1982 \mathrm{~b}$.

23 ALVES, 1982a, p. 36.

24 ALVES, 1982a, p. 29.

25 ALVES, 1982b, p. 124.

${ }^{26}$ REBLIN, 2009, p. 99-118.
} 


\section{Teologia, mística e poesia de Rubem Alves}

O que Rubem Alves escreveu sobre o modus operandi de igrejas e denominações protestantes associadas ao dogmatismo, intolerância e repressão, num determinado momento deixou de valer para sua experiência religiosa pessoal; ele tomou distância de tudo isso. Rubem Alves assumiu para a própria vida um dos lemas da Reforma Protestante: ecclesia reformata semper reformanda est. Contrapondo-se à maneira de utilização da linguagem que tende à cristalização do que é falado, Rubem Alves assumiu a poesia como linguagem privilegiada de sua teologia; e enriqueceu a tradição teológica latino-americana da libertação com uma obra teopoética.

Em diálogo com as proposições de Antonio Manzatto, pode-se associar a obra de Rubem Alves à teopoética por se localizar na liberdade da aproximação entre poesia e mística: "A linguagem poética, livre e paradoxal, pode melhor servir para expressar a relação com o mistério, e nesse sentido pode ser extremamente interessante para a experiência mística"27. A poesia foi para Rubem Alves o canal de expressão teológica, já que sua teologia desde as primeiras elaborações revela certa tensão em relação às regras acadêmicas. No prefácio à edição brasileira do livro Da esperança, resultante de sua tese de doutorado em Teologia defendida em 1968, Rubem Alves faz uma mea culpa:

Peço desculpas por ter escrito um livro assim tão chato. Eu não queria, porque eu não sou assim. Se escrevi desse jeito foi porque me obrigaram, em nome do rigor acadêmico. Eles pensam que verdade é coisa fria e até inventaram um jeito engraçado de escrever, tudo sempre impessoal, como se o escritor não existisse, e assim o texto parece que foi escrito por todos e por ninguém. E foi por causa desse frio que se interditou o aparecimento da beleza e do engraçado nos textos de ciência. O saber deve ser coisa séria, sem sabor $^{28}$.

Em contrapartida, teologia é algo que se faz por prazer, é jogo que se joga para celebrar a vida, pois ela não vale pela verdade das afirmações sobre Deus, mas pelo bem que faz ao corpo; não se pode falar de Deus, mas de coisas humanas, ele não se deixa apanhar por palavras humanas. ${ }^{29}$ Em entrevista não publicada até hoje ${ }^{30}$, embora tenha sido feita há mais de 20 anos, Rubem Alves comenta a especificidade de sua compreensão da teologia:

Você sabe, tem uma citação minha aqui [na dissertação]: "De Deus, o que podemos saber é o bem que faz ao nosso corpo". Sabe de uma coisa que me assombra, depois

27 MANZATTO, Antonio. Pequeno panorama de teologia e literatura. In: MARIANI, Ceci Maria Costa Baptista; VILHENA, Maria Ângela. Teologia e arte: expressões de transcendência, caminhos de renovação. São Paulo: Paulinas, 2011. p. 94.

28 ALVES, Rubem. Da esperança. Campinas: Papirus, 1987a. p. 9.

29 ALVES, 1987a.

${ }^{30}$ MARIANI, Ceci Maria Costa Baptista. A espiritualidade como experiência do corpo. São Paulo: Pontifícia Faculdade de Teologia N. Sra. da Assunção, 1997. (Dissertação de mestrado.) 
que fiquei velho, começo a rever a teologia, o que as pessoas disseram... Por exemplo, isso aqui é uma reformulação de uma fórmula da Teologia Reformada do séc. XVI, e é na verdade a negação da possibilidade do conhecimento de Deus, isto é, Deus, tal como ele é em si mesmo, não posso ter a menor ideia. Existe uma fórmula antiga da filosofia de Kant que dizia isso: "Das coisas, tais como elas são em si mesmas, a única coisa que eu sei é o 'como eu sei das coisas', eu sou o centro do universo"31.

Sendo um intelectual pouco afeito às regras do pensamento institucional e tão somente racional, Rubem Alves assume a digressão como método, fazendo referência a belo texto de Roland Barthes:

O Barthes, no seu texto "A aula", diz que o método é a digressão. Ora, digressão não é método, é justamente não ter método. É a livre associação. O método é assim: quero ir daqui para lá, então, estabeleço um caminho que me leva até lá. Na digressão, o interesse não é chegar lá, mas estar indo. Pode-se de repente reconhecer um caminho interessante e mudar de rumo. Isso é que é digressão.

$[\ldots]$

Pois é, a razão marcha em linha reta e o inconsciente dança. [...] Sabe que uma vez uma moça do Rio Grande do Sul me escreveu perguntando de que teoria eu lançava mão para escrever as minhas histórias infantis. Eu respondi que de teoria nenhuma. De repente a história aparece na minha cabeça, não tem método. Na verdade, se você tiver um método, não escreve nenhuma história. As histórias são aparições. Uma coisa, no entanto, é necessária, o grão de areia. Se não tiver o grão de areia, ela não aparece. ${ }^{32}$

O corpo e a emoção são elementos centrais na constituição da teologia, que é, para Rubem Alves, tecida com palavras boas para serem comidas, diferentemente da ciência que se faz com palavras boas para serem pensadas. ${ }^{33}$ A teologia é poema do corpo:

Teologia é um jeito de falar sobre o corpo. / O corpo dos sacrificados. / São os corpos que pronunciam o nome sagrado: / Deus... / A teologia é um poema do corpo, / o corpo orando, / o corpo dizendo as suas esperanças, / falando sobre seu medo de morrer, / sua ânsia de imortalidade, / apontando para utopias, / espadas transformadas em arados, / lanças fundidas em podadeiras... / Por meio dessa fala / os corpos se dão as mãos, se fundem num abraço de amor, / e se sustentam para resistir e para caminhar ${ }^{34}$.

A poesia passa a ser a linguagem que propicia a expressão da experiência espiritual do mistério que se dá no corpo. Deus, para Rubem Alves, habita o inconsciente, lugar das emoções mais profundas. Na mesma entrevista, o teólogo esclarece sua compreensão de inconsciente:

31 MARIANI, 2000, p. V.

32 MARIANI, 2000, p. X.

33 ALVES, 1987a.

34 ALVES, Rubem. Variações sobre a vida e a morte: o feitiço erótico-herético da teologia. 3. ed. São Paulo: Paulinas, 1989. p. 9. 
O inconsciente, para mim, é socrático. Sócrates conta que Diotima lhe disse, está no Simpósio, que todos nós estamos grávidos de beleza. Eu acho que a essência da alma é a beleza, é música. Você tem também fezes no caminho, claro que tem, mas isso não é a coisa, você mexe com isso só para chegar na beleza. Isso é coisa dos poetas. $\mathrm{O}$ inconsciente é a Bela Adormecida. Você conhece aquele poema do Fernando Pessoa? Então, nesse sentido, eu sou completamente contrário aos psicanalistas. A minha psicanálise é estética. Quero procurar o que existe de bonito. A beleza é que nos salva! O inconsciente, para mim, é isso! É como fala Fernando Pessoa: "Leio o que escrevi. E eu me pergunto: mas como, se nunca pensei nisso?" [...]. Eu não gosto muito do conceito freudiano de inconsciente porque para Freud o inconsciente é um conjunto de coisas recalcadas. Eu acho isso muito pobre. A minha imagem de inconsciente é mais teológica. Ele é esse imenso oceano de mistério que passa por dentro de mim, e não só o produto de um processo de recalque. $\mathrm{O}$ inconsciente, para mim, tem a ver com o inefável, com aquilo que não posso dizer, com o poético. É contato com o grande mistério ${ }^{35}$.

A percepção da dinâmica do inconsciente como lugar do desejo mais profundo é central na teologia de Rubem Alves: o humano é fundamentalmente corpo desejante, pois é habitado por um grande Vazio, com letra maiúscula porque é o Vazio originário, que nada pode preencher, o útero absoluto dentro do qual cada um é gerado/criado: "O Pai nosso que mora nos céus, onde voam as aves, espaço vazio, pura permissão, ausência" ${ }^{36}$. Vazio, presença de uma ausência que mora na profundidade, é o que põe a alma em movimento. A vida é a busca de realização do desejo absoluto que se dá num itinerário de travessia e ultrapassagem de tantas experiências de prazer e dor que se dão na relação com o mundo e com o outro.

É possível captar no fundamento da teopoética de Rubem Alves uma espiritualidade mística; seus escritos teológicos, priorizando a linguagem poética, deixam transparecer um itinerário espiritual que pode ser caracterizado como místico, pois traduzem uma experiência que pode ser compreendida no quadro de certa tradição mística, a da teologia negativa. Conforme a discussão introdutória deste artigo, mística está a se referir à experiência que implica um trabalho pessoal de ascese que conduz ao encontro direto com algo ou alguém que ultrapassa os limites de capacidade humana de compreensão, embora esse encontro seja descrito nas narrativas místicas como uma experiência cognitiva. Trata-se de uma experiência que ultrapassa também as capacidades humanas de apreensão volitiva, embora atraia o objeto de um desejo fundamental.

A mística que está no fundamento da teopoética de Rubem Alves se caracteriza por essa maneira interessante de lidar com o desejo. Sem negar o corpo, ele entende que a realização humana supõe, no entanto, uma ascese do desejo, isto é, um processo em que a vivência de si como um ser desejante encontra-se sempre tensionada pela percepção do Vazio originário, o Mistério inefável e inominável que habita a profundidade, o fundo da alma: "Será isto que é a alma, a Ausência que mora em mim, e faz

\footnotetext{
${ }^{35}$ MARIANI, 2000, p. XI.

36 ALVES, Rubem. Pai Nosso: meditações. São Paulo: CEDI; Paulinas, 1987b. p. 43.
} 
meu corpo tremer?"37. A vida, então, desabrocha em liberdade e alegria verdadeiras na medida em que o humano cumpre o itinerário que implicará também e, principalmente, aprender lições do abismo.

\section{Rubem Alves e as lições do abismo}

No já citado prefácio do livro Da Esperança, Rubem Alves toca implicitamente o tema da teologia da planície ou abismo: "Minha teologia nada tem a ver com teologia. / É vício. / Há muito que deveria ter abandonado este nome. / E dizer só poesia, ficção" 38 . A crônica passa a ser seu estilo, pois é símbolo da escatologia realizada, expressa a parusia de cada instante.

Num momento. Tenho a felicidade instantânea, na hora. Ela aparece! Isso é a coisa mais maravilhosa da crônica. Vou te dar um exemplo. Tem um livro que gosto muito [de autoria dele], O poeta, o guerreiro, o profeta. Porém, ele não deslanchou, não é muito conhecido. Não é bom de ler, os capítulos são muito compridos. A crônica é curta, você lê em qualquer lugar, até na sala de espera do consultório médico. Isso, inclusive, está sendo importante para a minha produção literária. O meu estilo mesmo são as crônicas. ${ }^{39}$

Diferentemente do tempo em que escreveu o livro A Theology of Human Hope ( $D a$ esperança, em português), considerado uma das primeiras obras de teologia da libertação, essa mudança de estilo reflete também uma nova maneira de conceber a história, de abandono da perspectiva clássica cristã, que entende a história como a conduzir a certo objetivo, para a adoção da ideia de uma escatologia realizada. Seu olhar deixa de estar voltado para a construção de um futuro por meio da ação política. Sua atenção se fixa nos sinais de transcendência do tempo presente.

Quando escrevi a Teologia da Libertação [referência ao livro A Theology of Human Hope, cujo título em inglês poderia ter sido Towards a Theology of the Liberation], isso era muito claro, o corpo tem um projeto de fazer história. Hoje eu não acredito mais na história. Claro que eu acredito nos acontecimentos, numa lógica que permite a existência de uma ciência histórica. Mas naquela ideia clássica cristã de que a história te conduz a um certo objetivo, eu não acredito mais. Creio que existem dois tipos de escatologia. A chamada escatologia consistente, aquela que diz que o fim está lá, o escaton, a parusia, o Reino de Deus, a sociedade sem classe... uma utopia a ser realizada. Porém, existe outra. Quando Jesus conta a história do trigo e do joio, onde o fazendeiro diz: "Você quer que tiremos o joio?". E Jesus responde que não, deixa... Essa história não tem solução, não conduz a nada. Pois bem, eu adoto hoje uma outra escatologia, chamada escatologia realizada. Cada momento tem sua parusia. ${ }^{40}$

${ }^{37}$ ALVES, 1987b, p. 18.

38 ALVES, 1987a, p. 24.

${ }^{39}$ MARIANI, 1995, p. VIII-IX.

${ }^{40}$ MARIANI, 1995, p. III-IV. 
De fato, vários dos escritos alvesianos em estilo de crônicas ou histórias infantis passaram a ser lugares privilegiados de expressão legítima de uma aproximação contemplativa entre poesia e mística, que caracteriza a teopoética do autor; belos textos que revelam também a atenção para os sinais atuais da realidade definitiva, que são motivos de esperança, sinais de transcendência. Dentre esses escritos, destaca-se, aqui, o livro A planície e o abismo como obra exemplar para a compreensão da teopoética de Rubem Alves. Publicado em 1991, ele é parte da coleção Estórias para pequenos e grandes (Edições Paulinas), um conjunto de histórias escritas em torno de temas dolorosos com o intuito de oferecer símbolos às crianças (e também aos adultos) para poderem enfrentar as situações mais desafiadoras. A história, semelhante às narrativas místicas, descreve as etapas de um caminho de aprofundamento espiritual, que tem como meta a experiência do mistério da "Montanha Encantada"41.

O sujeito da narrativa é um jovem cavaleiro, personagem sem nome que habita a planície e cuja alegria reside numa boa convivência com os amigos de taverna: música, boa cerveja, conversa; na taverna, não há solidão. Esse jovem, entretanto, sempre que retorna à casa se depara no caminho com uma encruzilhada que lhe causa estremecimento: a encruzilhada onde começa a trilha que leva ao alto da montanha. Não se pode deixar de sentir na história a influência ou releitura do quadro protestante "Os dois caminhos". Se uma das características da narrativa mística é a liberdade em relação à tradição, então a releitura mística de Rubem Alves do quadro (ou mesmo da figura de um peregrino) ultrapassa a visão dualista de mundo. Para Rubem Alves, a ascese não implica negação do prazer que a vida proporciona neste mundo, mas a ultrapassagem do prazer para que se possa saborear melhor as coisas do mundo com alegria verdadeira.

Atualmente, estou insistindo muito na diferença entre prazer e alegria. O prazer sempre exige a presença do objeto. Quer dizer, se você tem prazer com um copo de vinho, tem que ter o copo de vinho. Depois de tomar três copos, você já não aguenta mais. A alegria, no entanto, acontece mesmo na ausência do objeto. E ela não tem fim, você nunca fica cheio, nunca fica satisfeito.

[...] Acho que a gente nunca transcende o desejo do contato físico que é sempre uma coisa muito boa. A experiência sexual ilustra bem isso. Sexo pode ser só prazer. Ora, do ponto de vista do prazer, a sexualidade é muito simples, pois está relacionada a uma série de reações fisiológicas, semelhantes ao prazer sexual dos bichos. Porém, junto com esse prazer, existe outra dimensão, aquela que tem a ver com orgasmo, coisa que vem de dentro. Neste sentido, você pode até brincar com a ideia de sacramento. Sacramento é isso, uma coisa material, que tem uma dose de prazer, mas que está ligada a uma palavra que dá a espiritualidade. Transcende, expande. ${ }^{42}$

${ }^{41}$ Propor uma redução de Rubem Alves a Friedrich Nietzsche não faria justiça nem à obra deste nem à daquele. Entretanto, também não é prudente negar a influência da filosofia (aforística) de Nietzsche em boa parte do corpus bibliográfico alvesiano. Do geral para o particular, é possível também estabelecer associações do cavaleiro em A planicie e o abismo com o Zaratustra nietzschiano (cf. NIETZSCHE, Friedrich Wilhelm. Assim falou Zaratustra: um livro para todos e para ninguém. 7. ed. Rio de Janeiro, 1994).

${ }^{42}$ MARIANI, 1995, p. VI-VII. 
A ascese que leva à experiência do mistério da "Montanha Mágica", em $A$ planície e o abismo, vai se dar justamente pelas lições do abismo. A história descreve um itinerário composto de várias etapas a serem ultrapassadas no enfrentamento de desafios abissais. A experiência mística é fruto de um caminho, uma jornada. É clássica na tradição mística cristã a expressão De triplice via, cunhada por São Boaventura para descrever as três etapas indispensáveis para a ascensão do humano à felicidade perfeita para a qual foi criado: a da progressiva purificação (via purgativa), a da iluminação (via iluminativa) e a da vida unitiva. ${ }^{43}$

[Cada uma das etapas] comporta a prática de exercícios indispensáveis e comuns às três vias: a meditação, a oração e a contemplação. A elas acompanham a prática de determinadas virtudes, como a humildade, e de exercícios minuciosamente especificados, como o exame de consciência, a mortificação, a reforma de vida, a contrição dos pecados, a via purgativa; a imitação de Cristo, a prática dos conselhos evangélicos e a devoção à Virgem, na via iluminativa; e o exercício do amor, a adoração como forma peculiar de oração, a devoção, a vida eucarística e a contemplação em suas formas mais perfeitas, na via unitiva. ${ }^{44}$

A doutrina espiritual de São Boaventura traduz as exigências de um itinerário que tem em vista o estado propriamente místico descrito por categorias apresentadas como graus sucessivos, dos quais a última fase é descrita como contemplação intelectual e sapiencial, como êxtase da inteligência e da vontade, como rapto e morte mística na condição de cessação do uso das faculdades. ${ }^{45}$ A finalidade última da atividade toda da vida humana, para São Boaventura, é a união com Deus através do amor.

Na história de Rubem Alves, o caminho de subida do cavaleiro começa quando numa noite, ao retornar para casa, depois de ter estado na taverna com os amigos, algo assustou o cavalo em que vinha distraidamente montado. Em consequência, o animal empinou e saltou em direção ao abismo. Na queda, o jovem voou desamparado, até encontrar um galho de árvore, no qual se agarrou para ficar assim: balançando sobre o nada. Começou, então, a ouvir uma voz, era seu anjo da guarda: “"-Não tenha medo do abismo' [...]. Os abismos dizem sempre a verdade. Eles têm a sabedoria a ensinar, se fizermos silêncio para ouvir sua voz"46. Para Rubem Alves, as muitas palavras cotidianas fazem calar a Palavra que contém a verdade; cobrem-na como roupa, escondem a nudez. Palavras que funcionam como proteção contra a Palavra que mora na profundidade. O barulho cotidiano distrai. No silêncio, os corpos recuperam o desejo adormecido e passam a sonhar, libertam as palavras que falam a verdade, olham para a própria nudez sem vergonha, sem proteção, com as mãos vazias de desejos e ansiedades por vantagens substitutivas, e se dispõem para a experiência da graça.

${ }^{43}$ SHELDRAKE, Philip. Espiritualidade e teologia: vida cristã e fé trinitária. São Paulo: Paulinas, 2005. p. 61.

${ }^{44}$ VELASCO, Juan Martín. Doze místicos cristãos: experiência de fé e oração. Petrópolis: Vozes, 2003. p. 80-81.

${ }^{45}$ VELASCO, 2003, p. 81.

46 ALVES, 1991, p. 10. 
O jovem, distraído com o ruído da taverna, reclamou o anjo, não teria escutado as lições do abismo que ele tentou lhe ensinar, e por isso mesmo estava ali: "Fui eu quem assustou o seu cavalo. Fui eu quem o agarrou sobre o abismo"47, disse o anjo, que teve de se fazer escutar por meio do emissário mais terrível, a morte. Rubem Alves nomeia três emissários que convocam o ser humano às lições do abismo. Os mais brandos são "o pôr do sol", que chama à consciência da finitude, e a "solidão", que faz ver imagens que residem "em nossas funduras" e falam sobre "nossas verdades". O terceiro é a morte, que dificilmente alguém consegue deixar de escutar. De fato, de acordo com a tradição mística, a consciência da finitude constitui importante passo no itinerário rumo ao encontro com o Mistério.

Pendurado sobre o abismo, o jovem recebeu do anjo as instruções sobre o itinerário a seguir para encontrar a verdadeira alegria, aquela que permite voar como borboleta: "Somos seres abissais. Depois de aprendermos as lições dos abismos, e somente então, poderemos voar como borboletas" ${ }^{48}$. Ao longo desse itinerário, esclareceu o anjo, o jovem deve passar pela árvore dos poetas mortos, pelo penhasco do conhecimento, pela caverna escura da aranha e pela gruta da memória. Três estágios de um mergulho no fundo de si mesmo, onde reside o grande Vazio, Vento/Evento que sopra do futuro e vem ao encontro do Desejo mais profundo, desejo que se revela na ausência de todo o poder, na mais profunda impotência.

Observa-se que o itinerário místico rumo à transformação de si pelo encontro com o Mistério supõe, em primeiro lugar, provar do fruto da árvore dos poetas mortos, poemas que fazem o corpo estremecer e têm poder para ressuscitar os mortos que moram em cada pessoa: "Você começará a sonhar sonhos que nunca sonhou. Você compreenderá que seu corpo é um poema encarnado. E você se sentirá bonito como nunca sentiu"49. Os poetas, esclarece o anjo, com sua arte de juntar Amor e Morte, fazem surgir uma Beleza que nenhum golpe pode destruir, pois o amor sem a morte é frouxo e a morte sem o amor é terrível. Não se pode negar que essa relação entre o amor e a morte está associada à mística cristã, isto é, ao mistério da cruz. De fato, só a poesia consegue mostrar a beleza que reside na dor de amor do doar a vida pelo outro. Na árvore dos poetas mortos, o jovem receberá como dádiva um berimbau, instrumento constituído de uma corda esticada por um arco. O berimbau é a metáfora do que são todos os seres humanos, explicou o anjo, a corda é o Amor, Eros; e o arco é a Morte, Tânatos. É na tensão entre o desejo infinito e a consciência da finitude que o humano desabrocha em liberdade. O medo da morte superado pela entrega em amor torna possível a realização da vocação fundamental de ser criado à imagem de Deus.

O segundo momento do mesmo processo está relacionado à experiência do conhecimento. No caminho que leva ao topo da montanha é preciso passar pelo "Penhasco do Conhecimento". A mística é uma experiência cognitiva, mas tem um caráter noético sui generis, que leva à aquisição de uma certeza subjetiva que não vem das condições

\footnotetext{
47 ALVES, 1991, p. 10.

48 ALVES, 1991, p. 15.

49 ALVES, 1991, p. 17.
} 
intelectuais de conhecimento, mas do contato com o Mistério que se encontra além das possibilidades humanas de compreensão. O conhecimento, avisa o anjo ao jovem, é coisa boa, possibilita ter olhos claros capazes de ver através da neblina, porém só é gracioso para os que aprenderam as lições dos poetas mortos. Apenas quem passou pela poesia poderá comer o Livro da Ciência: "Pois o Conhecimento que só mora na cabeça é logo esquecido. É preciso que ele more no lugar onde o sangue corre" ${ }^{\circ 0}$.

O terceiro passo desse itinerário é decisivo, pois implica um grande mergulho no fundo de si mesmo. Para empreender esse salto, entretanto, o cavaleiro há de observar a aranha que tece sua teia sobre o abismo pendurada por um fio que sai de seu próprio corpo. Esse último passo exige a coragem de saltar no vazio abrindo mão de seguranças externas, de todos os apoios. Esse salto, revela o anjo, possibilita ao cavaleiro penetrar a "Gruta da Memória", lugar dos sonhos e da saudade. Saudade que não é tristeza pela perda do que amamos nem desejo de voltar ao passado.

Na saudade saímos dos nossos pequenos desejos que moram nos caminhos do vale, e nos descobrimos diante de um grande desejo, que é a nossa verdade. Saudade é o lugar da busca do Grande Desejo, esquecido, perdido. [...] Na saudade descobrimos que pedaços de nós ficaram para trás. E descobrimos, na saudade, uma coisa estranha: desejamos encontrar, no futuro, aquilo que já experimentamos como alegria no passado. ${ }^{51}$

Na profundidade abissal do humano habita uma grande Ausência, uma $\mathrm{Au}-$ sência absoluta, originária, geradora do desejo mais fundamental, aquele a que se chega quando se ultrapassam os pequenos desejos. Esse desejo fundamental é o que desloca o ser humano em direção ao futuro definitivo em que se dá a realização de si no cumprimento de sua genuína vocação humana. $\mathrm{O}$ trabalho espiritual de ascese tem como objetivo a transformação de si pelo enfrentamento do grande Vazio que habita a profundidade, deixado por uma Presença/Ausência, o grande Mistério Santo que se revela na promessa de uma vida nova.

Chega, então, o desfecho da história, o Anjo da Guarda tira o jovem do abismo e o coloca em terra firme para que ele inicie sua jornada rumo ao cume da Montanha. Depois de atravessados os "patamares" do itinerário previsto pelo anjo, o cavaleiro chega ao alto, entretanto, transformado: ele já não era o mesmo. Ali, no cume da montanha, o extraordinário aconteceu, uma Borboleta luminosa pousou em sua mão: "E ali ficaram eles, como dois namorados, naquele efêmero eterno momento místico, que nenhum poeta, nenhuma ciência, nenhuma saudade jamais pudera dizer"'52. Desejo, Saudade, Ausência, Vazio são, na obra de Rubem Alves, palavras/experiências do corpo que traduzem um tipo de relação de acolhimento entre humano e divino. Deus e o humano não são existências paralelas, são existências que se contêm. Um acolhe o outro.

Estando o cavaleiro no alto, soprou um vento forte, e no final do itinerário ele se percebe nu como se tivesse acabado de nascer:

\footnotetext{
50 ALVES, 1991, p. 21.

51 ALVES, 1991, p. 24.

52 ALVES, 1991, p. 27.
} 
A Borboleta Encantada foi ficando transparente e começou a desaparecer - e ele foi se sentindo cada vez mais leve, como se tivesse asas, como se pudesse voar sobre o Abismo. Não, a Borboleta não desaparecera. Agora ela morava dentro do seu próprio corpo. Ele era a Borboleta que havia aprendido as lições dos abismos. Nenhum golpe poderia matá-la ${ }^{53}$.

A aventura do cavaleiro, entretanto, não termina no alto da montanha. A experiência mística para Rubem Alves não termina em fuga do mundo. Depois de trilhar o itinerário que o levou à transformação de si, o jovem volta ao vale, aos mesmos amigos e às mesmas celebrações, porém, sem o mesmo sorriso, pois "traria sempre dentro dele o mistério da Montanha Encantada" "54. A mística se desdobra, portanto, em nova sensibilidade, nova forma de pensar e nova maneira de ação.

\section{Considerações finais}

De dentro do mundo protestante, e até mesmo contra ele, Rubem Alves deixou como legado para a teologia e sociedade uma obra com características místicas, que se soma de forma original à tradição que sabe da inefabilidade do divino e que o afirma através da via negativa como Mistério Santo, ou como o Totalmente Outro. Em Rubem Alves, Deus é Vazio, Ausência, Saudade. A ousadia do autor é, de fato, boa testemunha do potencial crítico da mística, pois faz ver também que, uma vez institucionalizada, toda experiência religiosa - e com o protestantismo não poderia ser diferente - acaba presa nas malhas da organização.

Em contrapartida, observa-se também em seus escritos a afirmação do Mistério Santo como Presença, que se capta como Desejo Profundo e que conduz a uma vida nova, plena de alegria, advinda de um itinerário que supõe a ascese do desejo. Trabalho interior que não implica negação do desejo, mas uma espécie de simplificação pelo aprofundamento.

A teopoética de Rubem Alves, trazendo a centralidade do corpo e das emoções à teologia, é a linguagem por excelência a anunciar o itinerário espiritual que move o humano ao encontro do Mistério, a expressão alegre e angustiada da Ausência Absoluta que habita as funduras humanas e confere sentido a seu caminhar neste mundo, que tanto vale amar.

\section{Referências}

ALVES, Rubem. Dogmatismo e tolerância. São Paulo: Paulinas, 1982a. . Protestantismo e repressão. 2. reimp. São Paulo: Ática, 1982b. . A menina e o Pássaro Encantado. 2. ed. São Paulo: Loyola, 1986. Da esperança. Campinas: Papirus, 1987a.

\footnotetext{
53 ALVES, 1991, p. 29.

${ }^{54}$ ALVES, 1991, p. 29.
} 
Pai Nosso: meditações. São Paulo: CEDI; Paulinas, 1987b.

ALVES, Rubem. Variações sobre a vida e a morte: o feitiço erótico-herético da teologia. 3. ed. São Paulo: Paulinas, 1989.

. A planície e o abismo. São Paulo: Paulinas, 1991.

BOUYER, Louis. Mystique. Essai sur l'histoire d'un mot. Supplément à la Vie Spirituelle, $\mathrm{n}$. 9, p. 3-23, 15 maio 1949.

CAMPOS, Breno Martins; MARIANI, Ceci Maria Costa Baptista. Peter Berger e Rubem Alves: religião como construção social entre a manutenção do mundo e a libertação. Protestantismo em Revista, v. 36, p. 3-20, jan./abr. 2015. Disponível em: <http://periodicos.est.edu.br/index.php/ nepp/article/view/2396>. Acesso em: 27 mar. 2018.

MANZATTO, Antonio. Pequeno panorama de teologia e literatura. In: MARIANI, Ceci Maria Costa Baptista; VILHENA, Maria Ângela. Teologia e arte: expressões de transcendência, caminhos de renovação. São Paulo: Paulinas, 2011. p. 87-98.

MARIANI, Ceci Maria Costa Baptista. A espiritualidade como experiência do corpo. São Paulo: Pontifícia Faculdade de Teologia N. Sra. da Assunção, 1997. (Dissertação de Mestrado em Teologia.)

MCGINN, Bernard. As fundações da mística: das origens ao século V. São Paulo: Paulus, 2012. Tomo I.

NIETZSCHE, Friedrich Wilhelm. Assim falou Zaratustra: um livro para todos e para ninguém. 7. ed. Rio de Janeiro, 1994.

PSEUDO-DIONÍSIO AREOPAGITA. Teologia Mística. Rio de Janeiro: Fissus, 2005.

REBLIN, Iuri Andréas. Outros cheiros, outros sabores...: o pensamento teológico de Rubem Alves. São Leopoldo: Oikos, 2009.

SCHILLEBEECKX, Edward. História humana, revelação de Deus. São Paulo: Paulus, 1994. SHELDRAKE, Philip. Espiritualidade e teologia: vida cristã e fé trinitária. São Paulo: Paulinas, 2005. VELASCO, Juan Martín. Doze místicos cristãos: experiência de fé e oração. Petrópolis: Vozes, 2003. 